\title{
THE IMPORTANCE OF BEING QUASI- DEMOCRATIC -THE DOMESTICATION OF INTERNATIONAL HUMAN RIGHTS IN AMERICAN AND ARAB POLITICS
}

\author{
David Mednicoff*
}

\begin{abstract}
The paper builds on a comparative treatment of the politics of contestation and incorporation of human rights law in the United States, Morocco and Tunisia to highlight the salience of international law's democratic legitimacy problems of popular representation and mobilization. The author shows that Morocco enjoyed the most sustained and broadest recent mobilisation of these cases in the domestic extension of international human rights norms. This finding suggests four conclusions. First, democratic legitimacy problems for international law are similar across more and less democratic regime types. Second, the democratic legitimacy problem allows states to use populist appeals to justify their internal deviations from international legal norms. Third, international human rights norms stand the best possibility of mitigating these legitimacy concerns and permeating domestic practice when they have a basis in a pattern of contestation that engages more than a narrow elite, and which might therefore be called quasidemocratic. Fourth, these points demonstrate the imperative of comparing the political processes for the domestic incorporation of international law across different spaces and regime types.
\end{abstract}

\section{INTRODUCTION}

I start from the general premise that international law has democratic legitimacy problems. My analysis proceeds from two basic concerns contained in the discussions of José Alvarez and others on this issue. While democratic legitimacy can be viewed through various theoretical lenses, two basic criteria are citizens' potential to participate in political outcomes and to elect officials who

* AB, Princeton; AM, JD, PhD, Harvard; Fulbright Visiting Professor, International Affairs Program, Qatar University, Doha, Qatar, on leave from the Department of Legal Studies and Center for Public Policy and Administration at the University of Massachusetts - Amherst. The author wishes to acknowledge the support of the American Society for International Law and the College of Social and Behavioral Sciences at UMASS, as well as the insights of my colleagues in the Four Societies Symposium. 
represent their interests or desires. ${ }^{1}$ Most people's lack of direct voice in the content or institutions of international law undermines participation legitimacy. Citizens' inability to elect delegates to the United Nations or other international bodies threatens representational legitimacy.

Since, in the contemporary world, the force and enforcement of international law are still open to challenge, and the democratic legitimacy of domestic legislative processes is not always clear, how much should we concern ourselves with international law's participatory and representational credentials? I argue below that there are grounds for significant unease, based on a brief comparative treatment of the politics of contestation and incorporation of human rights law in the United States and the two Arab cases of Morocco and Tunisia. The study shows that the most sustained recent process among these three of the domestic extension of international human rights norms occurred in Morocco, the case in which mobilisation around rights norms also bridged the broadest coalition of political actors.

This finding suggests four conclusions. First, democratic legitimacy problems for international law are similar across more and less democratic regime types. Second, the democratic legitimacy problem allows states to use populist appeals to justify their internal deviations from international legal norms. Third, international human rights norms stand the best possibility of mitigating these legitimacy concerns and permeating domestic practice when they have a basis in a pattern of contestation that engages more than a narrow elite, and which might therefore be called quasidemocratic. Fourth, these points demonstrate the imperative of comparing the political processes for the domestic incorporation of international law across different spaces and regime types.

My analysis unfolds in four sections. First, I offer brief framing reflections about democratic theory and international human rights law. Second, I use a short summary of the representation and participation concerns of the domestic use, particularly by federal judges, of human rights in the United States to suggest the seriousness of the democratic legitimacy problem. Third, I consider the Moroccan and Tunisian cases of the contestation of human rights, as well as their comparability with recent American experience of international law's democratic legitimacy issues. Fourth, I show how the results of my comparison yield the four concluding points enumerated above.

1 I address below mainly the direct representative and participatory elements of democracy, as well as the political domination of elites. Space limitations preclude discussion of broader recent dimensions of democratic theory, such as the literature on deliberative democracy. See, for example, Amy Gutman and Dennis Thompson Why Deliberative Democracy? (Princeton University Press, Princeton, 2004) or Ian Shapiro "The State of Democratic Theory" in Ira Katznelson and Helen V Milner (ed) Political Science: State of the Discipline (WW Norton, New York, 2002) especially 237-9. Whether the concept of deliberative democracy can connect meaningfully to the international legal sphere is, in any case, unclear, while the two general challenges to democratic legitimacy that I mention are more evident; see Thomas Risse "Transnational Governance and Legitimacy," unpublished paper, available at www.atasp.de (accessed 29 December 2006) 16-19. 


\section{DEMOCRATIC THEORY AND INTERNATIONAL HUMAN RIGHTS LAW}

If democracy most obviously requires clear mechanisms for its subjects to exercise their voice, then international law is not democratic. Neither of the two most common categories of democratic voice, direct citizen participation in decision-making and the delegation of decisions to elected representatives, exists in international law. More subtle problems such as the arcane nature of many international legal issues, the number of political levels between citizens and international legislative bodies, and the inclusion in international organisations of governments that themselves lack democratic accountability further muddy the potential for the international legal process to be democratic. Ordinary people have no regular procedure to formulate or approve international law, while increasing elements of their lives are governed by it.

If international law lacks basic democratic voice, this concern may be mitigated in diverse ways, some of which are pursued elsewhere in this issue. The elitist nature of the international legal process may be muted by its similarity to the actual practice of domestic politics in states that call themselves democratic. The presence of an increasing number and diversity of NGOs may represent a process analogous to interest groups in domestic governments that provide some mechanisms for voice, however unformalised. The difficulty and global nature of international legal issues may make some non-democratic processes desirable, or efficient, particularly given broader governance defects in the contemporary world order. Or perhaps the growth of international law, however it occurs, itself facilitates and lays the groundwork for democracy, despite defects in its current democratic process.

This last argument suggests the utility of focusing on human rights as a subfield for considering the reach of the democratic legitimacy problem. Human rights law might advance global democracy for at least two reasons. First, secure human rights, particularly civil liberties, may be among the preconditions for building or strengthening democratic government, whether by facilitating popular discourse and participation, buttressing citizens', legislators' and judges' autonomy, or other means. ${ }^{2}$ Second, given the empowering nature of human rights, most individuals would likely choose them if freely asked. ${ }^{3}$ If diverse people have favoured or would favour human rights, this area of international law enjoys some presumption of quasi-democratic legitimacy. ${ }^{4}$

Thus, human rights law's potential to serve democratic development or presume widespread global support may make the best case for overcoming worries about its non-democratic

2 See generally Jack Donnelly Universal Human Rights in Theory and Practice (2 ed, Cornell University Press, Ithaca, 2002).

3 For a similar, more elaborate justification of human rights, see Charles R Beitz "Human Rights as Common Concern" (2001) 95 American Political Science Review 269, 278.

4 See, for example, Thomas M Franck Fairness in International Law and Institutions (Oxford University Press, New York, 1995). 
promulgation, though the problem still exists. Human rights have been composed and contested through international elites. They become part of a country's framework of legal protections through a complex internal political process that can encompass leaders, legislatures, judges, NGOs and, less frequently, ordinary citizens. The more that this process represents or is driven by a wide range of a country's population, the greater its claim to entail democratic voice. My overview below of the contestation of international human rights in the United States and several Arab cases suggests that a more representative process may also plant these rights in firmer domestic soil.

I compare the recent experiences of the domestication of human rights law in the United States, Morocco and Tunisia for several reasons. Most simply, the fact that democratic deficit issues in international law play out in both Western and non-Western contexts implies the use of comparing these contexts. If social scientists increasingly question the value of rigid distinctions between democracies and non-democracies, ${ }^{5}$ little inherent reason exists to isolate the former in theorising international law's popular accountability. ${ }^{6}$ More specifically, my analysis below suggests that governments contest the domestication of international human rights in part through reference to other national contexts. Thus, considering diverse country cases in terms of the politics of international law may not only be useful, it may be essential to capture critical transnational dynamics.

My comparison of three diverse cases yields a possible paradox. Because of the well-established role of judicial review in the United States, judges have been the primary source of the domestic incorporation of international human rights, although this highlights the problems of democratic accountability of an unelected judiciary. The weakness of judicial review in Arab states means that human rights reform there has been largely a result of pressure from outside of the government. In this sense, the incorporation of human rights might be said to have been more democratic in Arab countries, and particularly, in Morocco, than in the United States.

\section{INTERNATIONAL HUMAN RIGHTS IN THE US AND THE DEMOCRACY DEFICIT}

Another reason to juxtapose questions about the democratic legitimacy of international law in non-Western societies to that of the United States may be the latter's political and legal exceptionalism among functioning democracies. ${ }^{7}$ American exceptionalism regarding international

5 See, for example, Atul Kohli "State, Society and Development" in Ira Katznelson and Helen V Milner (ed) Political Science: State of the Discipline (WW Norton, New York, 2002) 84, 117.

6 José E Alvarez "Do Liberal States Behave Better? A Critique of Slaughter's Liberal Theory" (2001) 12 EJIL 183.

7 See generally, Harold Hongju Koh "On American Exceptionalism," (2003) 55 Stan L Rev 1479, Seymour Martin Lipset, American Exceptionalism: A Double-Edged Sword (WW Norton, New York, 1996) and Charles Lockhart The Roots of American Exceptionalism: History, Institutions and Culture (Palgrave Macmillan, New York, 2003). 
human rights is highlighted by two divergent facts. First, the United States played the central role in laying the jurisprudential ground and in creating the momentum in the 1940s for the founding document of contemporary international rights, the Universal Declaration of Human Rights (UDHR) ${ }^{8}$ However, despite the historical role played by Americans in crafting the UDHR, in recent years the elected branches of government have shown more resistance to the incorporation of international human rights standards than have their counterparts in other Western democracies. This approach has hardened further in the policies of the United States since 9/11/01.

Nonetheless, the critical United States role in the globalisation of human rights ideology and standards ${ }^{9}$ implies a great deal of congruence between many international rights and those accorded to American citizens. Human rights conflicts in the United States thus take place within a broad consensus between citizens and government that assumes the centrality of civil liberties. The pattern of regime deviation from international rights, unless there is significant contestation around rights issues, may be similar in Washington and some Arab regimes. At the same time, the United States government's degree of basic embrace and observance of fundamental rights, even since $9 / 11 / 01$, is qualitatively different than that of many other political systems.

International rights treaties become United States law only after ratification through domestic legislative processes. One aspect of United States human rights exceptionalism is that the Senate has refrained from ratifying many recent rights treaties, including the International Covenant on Economic, Social and Cultural Rights, ${ }^{10}$ the Convention on the Elimination of Discrimination Against Women (CEDAW) ${ }^{11}$ and the Convention on the Rights of the Child. ${ }^{12}$ Washington has also declared that it will not ratify the Rome Statute for the International Criminal Court. Executive and legislative branch leaders who have discouraged the writing into American law of international human rights instruments claim that the citizens whom they represent either believe that American law guarantees sufficient rights without the need for international law, that the United States' global position would subject it to heightened, unfair scrutiny should these treaties be ratified, or both. ${ }^{13}$

8 See, for example, Mary Ann Glendon A World Made New: Eleanor Roosevelt and the Universal Declaration of Human Rights (Random House, New York, 2002).

9 Louis Henkin "Human Rights: Ideology and Aspiration, Reality and Prospect" in Samantha Power and Graham Allison (eds) Realizing Human Rights: Moving from Inspiration to Impact (St Martin's Press, New York, 2000) 4, 25.

10 International Covenant on Economic, Social and Cultural Rights (16 December 1966) 993 UNTS 3.

11 Convention on the Elimination of Discrimination Against Women (18 December 1979) 1249 UNTS 13.

12 Convention on the Rights of the Child (20 November 1989) 1577 UNTS 3.

13 See, for example, the remarks of John Bolton, former United States Undersecretary of State for Arms Control and International Security and Ambassador to the United Nations (UN) "American Justice and the International Criminal Court" (Remarks at the American Enterprise Institute, Washington DC, 3 November 
If true, these claims would imply that limits in the incorporation of international rights into federal United States law simply demonstrate the correct way in which democratically-elected representatives understand their constituents' will, given the low involvement of most Americans in international issues. However, Americans' actual views on international law and policy are often unclear; apathy can be a function of the manipulation of leaders, particular media outlets' spin or the framing of survey research questions. ${ }^{14}$ Thus, lack of legislative or executive expansion of international human rights in the United States may prove little more than the difficulty of claiming that recent treaties enjoy unimpeachable domestic democratic legitimacy.

In the absence of elected officials' affirmation of recent rights treaties, customary norms derived from these treaties have influenced, if not determined, American legal standards through federal judges' reasoning that customary international law can have binding legal status akin to federal common law. This is part of a broader Western trend has been described as "creeping monism." It derives from a general statement in an early $20^{\text {th }}$-century case that United States law includes international law, ${ }^{15}$ which has been affirmed in recent cases, ${ }^{16}$ but has only been applied to case outcomes to a limited extent, notably in allowing foreign nationals jurisdiction to sue other foreign nationals for torture under the Alien Tort Statute. ${ }^{17}$ In most cases in which international human rights norms are cited by United States judges, such norms, or their acceptance by other democracies, are used as limited evidence for the soundness of a particular legal position, rather than as controlling law. ${ }^{18}$

I refer to federal judges' use of international human rights, discussed in detail elsewhere in this issue, to consider the seriousness of the democratic legitimacy problem in a manner that may connect to the experiences of Arab countries. In this light, it is worth noting the controversy around customary international law's entrance into American common law through judges' rulings. ${ }^{19}$ The

2003) available at the State Department website www.state.gov (accessed 12 June 2006). On the points in this paragraph generally, see also Alvarez, above n 6, 194-5.

14 See, for example, the widely-publicised study of how exposure to diverse media sources produced major differences in Americans' attitudes towards war with Iraq in 2003, Program on International Policy Attitudes "Poll: Misperceptions, the Media and the Iraq War" (2 October 2003), available at www.worldopinion.org (accessed 1 March 2007).

15 The Paquete Habana (1900) 175 US 677, 700.

16 See for example, Texas Industries Inc v Radcliff Materials Inc (1981) 451 US 630, 641. Discussion of this topic was amplified by Justice Kennedy's oft-cited opinion referring to judgments of the European Court of Human Rights in Lawrence v Texas (2003) 123 S Ct 2472, 2481.

17 Filartiga v Pena-Irala (1980) 630 F 2d 876 (2d Cir).

18 Lawrence, above n 14, and Sosa v Alvarez-Machain (2004) 542 US 692.

19 Much of this controversy was kicked off by Curtis Bradley and Jack Goldsmith "Customary International Law as Federal Common Law: A Critique of the Modern Position" (1997) 110 Harv L Rev 815. 
purpose of doing so is not to dismiss the importance or legitimacy of the norms themselves, but to suggest the costs, and similarities across political regime types, of elite political action that poses significant counter-majoritarian concerns..$^{20}$ Thus, the issue is not whether American judicial use of unratified human rights treaties creates democratic legitimacy questions, but whether these questions can be otherwise resolved, as various scholars suggest.

One way of sidestepping democratic concerns is to note that United States federal judges tend not to rely on customary international law as controlling; rather, they cite international laws and analogous comparative precedents from Western democracies to rationalise a holding that already has an indigenous grounding. For example, when Justice Kennedy referenced European applications of human rights law as part of his opinion to invalidate anti-sodomy laws in Lawrence $v$ Texas, he was simply adding comparative experience to a general argument stemming from American law. ${ }^{21}$

A related point is that United States judges have applied customary international human rights in a sufficiently narrow manner to ease the immediate concerns of those who are uncomfortable with its potential to determine American case law. ${ }^{22}$ If used in a non-controlling way, international law that has not entered United States law through a representative or participatory democratic process should still be useful to American legal practice, especially given Washington's global role, as has been true throughout American political and legal history. ${ }^{23}$

Yet arguments that the counter-majoritarian democratic problem can be sidestepped are unlikely to satisfy many of those who raise it. ${ }^{24}$ Prior judicial restraint is no guarantee of future action. Indeed, what appears to be restraint may be judges' politically-strategic efforts to depend where possible on domestic law to legitimise a ruling they know will extend or implicate international norms. ${ }^{25}$ Justice Kennedy's directness in comparing Texas' and Europe's legal treatment of sodomy could be read as testing the waters to apply human rights law more generally. ${ }^{26}$ Thus, there is no

20 For example, see ibid and Paul B Stephan "International Governance and American Democracy" (2000) 1 Chi J Int'l L 237, 238.

21 Harold Hongju Koh "International Law as Part of Our Law" (2004) 98 Am J Int'l L 43, 54-5.

22 See Sosa, above n 16, for a recent example of this type of judicial reasoning.

23 Koh, above n 19, 47-9.

24 Stephan, above n 18, 246-7.

25 For a related example from Israel, based on a different concern about the risks judges run in trying to apply international legal norms, see Alvarez above n 6, 215-6.

26 See Bradley and Goldsmith, above n 19, for this concern. 
reason to believe that judicial use of unincorporated international rights avoids counter-majoritarian concerns at the federal level, to say nothing of problems with federalism and state law. ${ }^{27}$

The judicial anti-democratic argument can be resolved in at least two ways. One is to change the terms of the debate. For example, customary international law could be conceived as belonging to a juristic category other than straightforward federal common law, such as an advisory body of law. ${ }^{28}$ Or federal legislation could be enacted that clarifies the extent to which customary international law is incorporated into United States law, or at least allows government members to determine when executive or legislative acts are incompatible with customary international law. ${ }^{29}$

This approach might solve the democratic deficit problem, but depends on exactly the sort of legislative or executive action, hopefully driven by direct broad citizen mobilisation on international rights issues, that has been lacking in the United States generally in the post-September 112001 (9/11) climate. Questions of likelihood aside, this approach acknowledges the depth of the democratic problem. It admits that the way to resolve it is action that satisfies typical requirements of representational or participation legitimacy.

A second approach, which Harold Koh has suggested, downplays countermajoritarian differences between international and domestic legal processes; both comprise interaction, interpretation and internalisation. ${ }^{30}$ Any contemporary legal process has democratic features, as well as others that involve less general citizen input but nonetheless allow for accountability. The interaction of academics, NGO's, officials and foreign governments is a "time-honored dialogic process" that helps judges weigh the most varied and best evidence relevant to their ruling. ${ }^{31}$

This perspective does not resolve the basic problem of representative or participatory voice, especially given the elitist nature of international law's formulation, which relies on academics and professionals who may find the salience of their legislative roles corrupting. ${ }^{32}$ The democratic legitimacy problems remain, as the general lack of citizen voice in the international legal process can still be seen to subject Americans to laws not of their own making. ${ }^{33}$

27 T Alexander Aleinikoff "International Law, Sovereignty, and American Constitutionalism: Reflections on the Customary International Law Debate" (2004) 98 Am J Int'l L 91, 95-6.

28 Ibid, 95-6.

29 Ibid, 101-4

30 Koh, above n 19, 55-56, quoting Justice Stephen Breyer to make the point about legal systems in general.

31 Ibid, 56-57.

32 Stephan, above n 18, 245-7.

33 Aleinikoff, above n 25, 101. 
However, Koh's point remains useful in its invitation to look beyond the majoritarian representation and participation criteria of democracy to view the complex interplay of sociopolitical forces that account for and include judicial interpretations. ${ }^{34}$ If most people don't have direct voice either in international law's formation or its application in their country, not only may this be similar to most legal processes, but people may find voice by understanding participation in a more subtle, indirect way. ${ }^{35}$

For example, the one-nation one-vote process of legislation that occurs in some international legal fora entails one notion of participation equality and might be seen as relatively inclusive in the number of process levels in which people can participate. ${ }^{36}$ Indeed, the proliferation of NGOs in different places and issue areas arguably provides growing opportunity for diverse citizens to involve themselves in human rights law transnationally or domestically. Instead of highlighting unambiguous concerns for democratic voice, Koh's international process perspective encourages looking at judicial use of international human rights law in the United States as embodying part of a complex terrain of political contestation with quasi-democratic qualities.

This reinforces the analytic utility of a focus on human rights law, given its basic premise that governments, elected or not, are likely in practice to incorporate international rights only after significant pressure. If leaders incline more towards restricting rights than extending them, a process that engages diverse actors, if not the population as a whole, may be the most plausible way for international norms to be domesticated. After all, governments are likely to try to mute direct citizen voice favouring the incorporation of international human rights. National rulers' tendency to move against human rights expansion fits the general pattern in the United States after 9/11, and may be why some scholars see executive power, not international law, as the more significant threat to democracy in that country. ${ }^{37}$

Thus, the democratic legitimacy problem of human rights law in the United States can be rethought somewhat to seem less severe under conditions of diversified, robust rights contestation, even where this contestation falls short of representing or involving the participation of the general population. Doing this also facilitates comparing the political processes of rights domestication across diverse regimes. Indeed, it may be that federal judges are most prone to make customary or other use of unratified international human rights treaty norms precisely when they are aware that these norms have fostered a significant process of domestic contestation.

34 Risse, above $\mathrm{n} 1,10$. The author then proceeds to reiterate concerns about democratic legitimacy at 19.

35 This is similar to the democratic possibility of international custom which Nicole Roughan elaborates elsewhere in this issue.

36 See, for example, Sally Engle Merry, Human Rights And Gender Violence: Translating International Law Into Local Justice (University of Chicago Press, Chicago, 2006) 42.

37 Joel Richard Paul "Is Global Governance Safe for Democracy?" (2000) 1 Chi J Int'l L 263, 271. 
This brings back Justice Kennedy in Lawrence. He may have felt comfortable using comparative European precedent in this case in reflection of a broader American phenomenon. Issues affecting the equality of gay and straight citizens comprise the major recent example of an arena in the United States in which the content of rights has been contested in a quasi-democratic, and, at times, more directly democratic process. In other words, judges can take positions that explicitly implicate transnational law in part when those positions show evidence of reasonably broad social engagement. Yet, unlike some privacy and due process rights that have been at issue in the United States after $9 / 11$ and that entailed the mobilization of a narrow group of rights advocates and attorneys, most currently-litigated or contentious gay rights questions lack clear resolution in international human rights law.

Thus, one can envision a process in the United States of political contestation to enhance the domestic recognition of international human rights that includes enough social breadth and depth to mitigate deficits in unambiguous democratic voice. However, the United States does not provide a clear recent example of this process. For such an example, I turn towards a less obvious direction and a contrast between two comparable Arab cases.

\section{INTERNATIONAL HUMAN RIGHTS IN TWO ARAB CASES - TOWARDS A QUASI-DEMOCRATIC RESOLUTION?}

The general landscape for human rights incorporation in contemporary Arab contexts appears quite different from the United States. Civil rights are still far from the norm in Arab politics, which have been marked by the historical experience of colonial and post-colonial regimes loath to enforce, or even to endorse, democratic pluralism. Though an emphasis on the rule of law in political theory is as important in Arab Islamic history as in that of the United States, human rights norms are often associated with Western, and particularly, Anglo-American neo-colonial origins. ${ }^{38}$ Thus, discussions and dissension over whether international human rights should be part of domestic law take on more salience than they have in American politics. Moreover, the preponderance of power in most Arab polities in unelected rulers has limited the independence or incidence of judicial review. 39

One obvious consequence of these differences is that the locus of activity and potential concerns about democratic legitimacy for the domestication of international human rights law is not the

38 David Mednicoff "Middle East Dilemmas" in Thomas Carothers (ed) Promoting The Rule Of Law Abroad: In Search Of Knowledge (Carnegie Endowment for International Peace, Washington DC, 2006) $251,251$.

39 See, for example, Nathan J Brown The Rule Of Law In The Arab World: Courts in Egypt and the Gulf (Cambridge University Press, Cambridge, 1997) and Arab Center for the Rule of Law and Integrity and International Foundation For Electoral Systems (eds) State Of The Judiciary Report: Egypt 2003 (IFES State of the Judiciary Report Series, April 2004) available at www.ifes.org (accessed 1 April 2007) for an extended discussion and specific assessment, respectively, of the weakness of the judiciary in Egypt, where judicial review is by far the best-established of any Arab case. 
judiciary, but transnational and domestic civil society. Perhaps, then, one can speak only minimally of the legal incorporation of human rights norms in Arab countries. Many Arab states have become parties to human rights treaties. But they often lack an internal process for review and approval prior to ratification, raising the issue of domestic accountability. Thus, Arab human rights incorporation refers to a process of contestation that has come mostly from outside of the government. Indeed, indigenous rights activists have faced formidable barriers to their work of spreading international civil and political rights in Arab states. Hence, paradoxically, one can claim that international human rights law has made its way into Arab societies in possibly more democratic a manner than in the United States. In Arab cases, transnational human rights NGOs have been prominent in helping to create political pressures and space to galvanise local activism in Arab societies. ${ }^{40}$

In both Arab cases and the United States, the contestation and incorporation of international human rights standards have been elite-driven. Efforts by Moroccans and Tunisians to press for the local adaptation of human rights law have connected more directly to social mobilisation against more generalised patterns of authoritarian abuse. Indeed, it can be argued that, for better or worse, human rights has emerged as the only globally-recognised ideological frame for political resistance in non-western countries. ${ }^{41}$

During the 1980s and 1990s, the growth in activity of transnational human rights NGOs, their ability to make use of media and governmental networks to document and pressure regimes with patterns of violating their citizens' civil rights, and media globalisation all encouraged the framing of local pressures for Arab regime liberalisation in terms of human rights. ${ }^{42}$ Human rights thus emerged as a significant area of international law that could connect directly to domestic Arab politics, even if pressures from institutions such as the International Monetary Fund and World Bank on Arab countries to accept international free market legal norms have been at least as important.

Arab cases in which international human rights have been incorporated to a significant extent in domestic society have tended to follow a neo-Hegelian model of a "thesis" produced through social activism during the 1980s, an "antithesis" conveyed by the political system as a response and an eventual synthesis in which civil and political liberties are improved. More specifically, local human rights movements pushed for major increases in government transparency and the observance of internationally-protected civil liberties. The target government responded by trying to co-opt human rights discourse for itself, often creating a state-sponsored human rights panel or movement. In the

40 See, for example, Susan Waltz Human Rights and Reform: Changing the Face of North African Politics (University of California Press, Berkeley, 1995) 197-8.

41 Balakrishnan Rajagopal International Law From Below: Development, Social Movements And Third World Resistance (Cambridge University Press, New York, 2003) 171-3.

42 Waltz above n 38, and David Mednicoff "Think Locally - Act Globally? Cultural Framing and Human Rights Movements in Morocco and Tunisia" (2003) 7 Int J Hum Rts 72, 96-98. 
end, this strategy was only partially successful at keeping human rights criticisms at bay, leading to a gradual thaw in civil and political liberties. The monarchical government of Morocco is an example of such a case. The nearby military regime in Tunisia provides a counterexample, where the ruler has been able to rely on the threat of coercion to limit political rights, at least for the time being. In neither case is the development of judicial autonomy or review yet a significant political factor.

In countries like Morocco, indigenous human rights activists pressed to frame international human rights law in local terms starting in the late 1980s in part because doing so conveyed advantages in contesting state policy practices. North African rights activism combined a persuasive moral argument, the support of international NGOs and foreign governments, and the ability for activists to claim a neutral or apolitical agenda while nonetheless engaging in politics. ${ }^{43}$ Thus, at least one important aspect of the growth of human rights movements in Arab countries was the search for novel strategies of political engagement, as opposed to the unadulterated neutral rights monitoring that is sometimes claimed as the mandate of NGOs like Amnesty International. ${ }^{44}$ At the same time, Arab human rights organisations have done critical work in adapting human rights law to local understanding.

Despite the subsequent divergence in each country's human rights trajectory, Morocco and Tunisia both exhibited similar, relatively seamless, processes through which international human rights law was adapted for domestic use. In Morocco, the organisation that did much to create political space for human rights movements in civil society, the Moroccan Organisation for Human Rights (OMDH), had little trouble formulating a statement reconciling international human rights law with Moroccan norms. The only sticking point was the Moroccan Constitution's recognition of Islam as the state religion, which led the $\mathrm{OMDH}$, like many Arab groups engaged in political reform, to credit Islam as inspiring Moroccan human rights, while also recognising international rights formulations. ${ }^{45}$ The Tunisian League for Human Rights (LTDH) experienced a similar problem with the emphasis in the UDHR on freedom of religion. Because of the hostility of Islamic law and many Arab Muslims to the idea of converting out of Islam, the LTDH endorsed freedom to choose, but not to change, one's religion. ${ }^{46}$

Apart from the significant exception of squaring the established nature of state Islam with international human rights laws, neither of the dominant Moroccan or Tunisian human rights

43 Ibid, 14-5.

44 See, for example, the comments of the former president of Tunisia's major human rights organization, quoted in Kevin Dwyer Arab Voices: The Human Rights Debate In The Middle East (Berkeley, University of California Press, 1991) 180.

45 Waltz above n 38, 146.

46 Ibid, 138 
movements of the 1980s found it difficult to endorse the UDHR, including its provisions relating to gender equality. In countries like Morocco and Tunisia, where Islam did not take the socially puritanical form identifiable in Saudi Arabia or Sudan, international rights incorporation was not especially a question of cultural compatibility between international law and local practice. ${ }^{47}$ Rather, it was an issue of how to apply local pressures on regimes that were reluctant to extend political liberties.

This response itself tended to depend on two factors that were somewhat external to questions of international legal incorporation. First, Arab regimes were more likely to allow human rights contestation where it did not fan the flames of fear of political disorder among groups that were critical to stability. Second, Arab regimes were more likely to curb rights violations to mitigate pressure from international NGOs or from Western governments. These two factors, in turn, tended to inter-relate. Domestic support for rights abuses was more likely in situations in which foreign governments accepted these abuses, out of concerns, real or exaggerated, for domestic political stability.

This is primarily what drove divergence in the Moroccan and Tunisian cases. In Morocco, the royal regime of Hassan II had achieved a level of relative stability by the 1980s where political parties and other elements of civil society could organise openly. Moreover, the late Moroccan king based a good deal of his ideology of rule on his embodiment of Moroccan Islam. This meant that significant Islamic opposition to the regime was both less than in more secular Arab governments and under-reported by state media. ${ }^{48}$ Arab monarchies also tended to define their political ideologies less in contrast to Western countries and economies, unlike the pattern of military regimes, such as Syria, Iraq or Libya. As a rather open polity that fostered consistent ties to Western countries like France and the United States, Morocco was vulnerable to internal and external pressures on human rights issues. ${ }^{49}$ Organisations such as the $\mathrm{OMDH}$ were able to connect with transnational human rights movements and get the attention of Western journalists and leaders. An example of this occurred in 1990 when a book critical of Moroccan human rights practices was published by a French journalist, which, in turn, triggered a high-profile campaign by French Prime Minister

47 Despite the relatively smooth processes in Morocco and Tunisia, the conflict between NGOs' ideas about international human rights law and political implementations of Islam is an important issue that deserves thoughtful attention, which it has received recently in Naz K Modirzadeh "Taking Islamic Law Seriously: INGOs and the Battle for Muslim Hearts and Minds" (2006) 19 Harv Hum Rts J 191.

48 See, for example, Mohamed Tozy Monarchie et Islam Politique au Maroc (2 ed, Presses de Sciences Po, Paris, 1999).

49 Sieglinde Gränzer "Changing Discourse: Transnational Advocacy Networks in Tunisia and Morocco" in Thomas Risse, Stephen C Ropp and Kathryn Sikkink (eds) The Power of Human Rights: International Norms and Domestic Change (Cambridge University Press, New York, 1999) 109, 123-5. 
Francois Mitterand's wife, Danielle, and led to a temporary souring of official relations between Rabat and Paris. ${ }^{50}$

The globalisation of communications technology in the 1990s gave local and transnational rights activists additional capacity to document and express human rights concerns throughout the world. In Morocco, the increased pressure on the regime provoked a governmental counter-response, in the form of major international public relations efforts to document the country's pseudo-democratic features, and the creation of an official human rights advisory council linked to the royal palace. The regime's combination of vigorous democratic symbolic assertions, defensive posture regarding rights violations and the establishment of human rights bodies to serve its own agenda is an example of the process described above as the governmental "antithesis" to the "thesis" of violations asserted by rights movements.

In the Moroccan case, such efforts did not deter the growth of human rights movements or the national and transnational momentum to halt or expose major civil and political rights violations. Indeed, this momentum re-established itself when the regime tried too hard to counter it, and spanned diverse domestic political organisations. ${ }^{51}$ Along with the continuing globalisation of information propelled by the Internet, satellite television and cellular telephones, this momentum lowered Moroccans' tolerance for the regime's most infamous practices, such as those perpetrated in the political prison of Tazmamart. Towards the late 1990s, as the Moroccan king became increasingly infirm and concerned about ensuring a stable power transition to his son, Muhammed, international human rights were increasingly given effect in Moroccan law.

In Tunisia, by contrast, a different dynamic prevailed. The LTDH was a potent political force in the mid-1980s. But this was exactly the time that independent Tunisia's ageing founding father, Habib Bourguiba, was ousted by his lieutenant, Zine 'Abidine Ben 'Ali. When Ben 'Ali came to power in 1987, Tunisians in the political elite hoped that the LTDH could help realise the new leader's pledge to open up Tunisian politics after decades of increasing stagnation. Indeed, the first years of Ben 'Ali's presidency brought genuine liberalisation in Tunisian public life, during which elites and civil society that lay moribund under Bourguiba resurfaced. Ben 'Ali allowed several political parties to operate legally. He freed thousands of political prisoners, guided Tunisian ratification of several international human rights instruments and abolished a number of Tunisia's most repressive institutions.

However, Ben 'Ali's initial liberalisation also fostered the growth of the bete noire of contemporary secular Arab politics, a popular organisation advocating an entirely new regime based on Islamism, en-Nahda. After its first few years, Ben 'Ali's regime became increasingly repressive,

50 Marvine Howe Morocco: the Islamist Awakening and Other Challenges (Oxford University Press, New York, 2005) 117, 312.

51 Ibid, 253-5. 
ostensibly justified by a no-tolerance policy towards en-Nahda $a^{52}$ At the same time, Tunisia's staunch determination to remain open to Western tourism and economic interaction encouraged international quiescence to Ben 'Ali's authoritarian crackdowns, amplified by Western fear of Islamist government. This climate of repression has extended well beyond Islamist groups to limit almost all would-be outspoken elements of civil society, including human rights movements, thereby effectively stalling the push-pull process of rights activism, regime response and gradual political incorporation.

In a case like Morocco, where slow political opening partially responded to domestic human rights groups, both the rhetoric and reality of the incorporation of international human rights into local legal practice can be said to be present. ${ }^{53}$ Jordan, Lebanon, and several small Persian Gulf countries such as Kuwait and Qatar fit this model to some extent, though the relative stability that has allowed openings towards international human rights law in the Gulf have had more to do with oil revenues and leaders' initiatives than with regime responses to human rights pressures from political activists. ${ }^{54}$ Algeria is similar to Tunisia in the regime's success at keeping rights activism at bay by keeping citizens and foreign governments focused on concerns about political Islam. Egypt is something of a mixed case. In many ways the Arab society with the most well-developed judicial system and network of civil society, Egypt has nonetheless seen the internalisation of human rights law hampered by the Mubarak government's emphasis on combating Islamism and the US government's willingness to keep generous foreign aid flowing to the country out of fear of the regime's destabilisation.

The primary domestic difference between Morocco and Tunisia is the diversity of political pluralism in Morocco, an interesting constant in the kingdom's political life for most of the postcolonial monarchy. This pluralism included the development of an increasingly transparent election process for a two-chamber parliament, even though the actual legislative capacity of this body is minimal. It is precisely this pluralism which, together with the impact of international NGOs and the country's sensitivity to foreign opinion, has sustained a dynamic human rights development. ${ }^{55} \mathrm{In}$ Tunisia, human rights was a route through which long-repressed civil society could regroup and breathe in the early stages of Ben 'Ali's regime consolidation. But these breaths were gradually stifled through fears of Islamist politics and disorder.

52 Kenneth J Perkins A History of Modern Tunisia (Cambridge University Press, New York, 2004) 194-5.

53 Gränzer, above n 46, 133.

54 Michael Herb All in the Family: Absolutism, Revolution and Democracy in the Middle Eastern Monarchies (State University of New York Press, Albany, 1999).

55 Waltz above n 38 and, more generally, Marina Ottoway and Meredith Riley "Morocco: From Top-down Reform to Democratic Transition?" (2006) Carnegie Papers 71. 
In neither case did human rights pressures encompass a democratic process of widespread representation and participation. The advocacy groups and party activists who began the give-andtake of human rights incorporation in Morocco in the late 1980s were all members of the political elite and used their insider status to create pressures on the royal regime to initiate top-down reforms. Yet this process came to touch and even mobilise broader segments of the population. ${ }^{56}$ The much-touted 2004 reform of Morocco's mudawwana family code to approximate CEDAW norms on gender equality in marriage and inheritance received much attention for its broad quasidemocratic social mobilisation around an important contemporary rights issue. Indeed, the sustained pluralistic dynamic of human rights domestic extension in Morocco has fostered some discussion of a possible democratic transition in that country, suggesting the link between the growth of human rights and democratic development noted earlier in this essay. ${ }^{57}$

Thus, the internalisation of international human rights law in Morocco suggests the possibility that such a process might be quasi-democratic and democratising; it provides some reason to believe, as I have argued elsewhere, that human rights as a frame for social activism can appeal to a wide array of people. ${ }^{58}$ Yet, in the United States and Tunisia, quasi-democratic framing of international human rights issues has not taken hold recently, and the general democratic legitimacy problem of this area of international law remains intact. I turn back now to the ongoing salience of this problem, and its not-coincidental connection to government opposition to international human rights law.

\section{COMPARING INTERNATIONAL LAW'S DEMOCRATIC DEFICIT ACROSS REGIMES}

The preceding analysis suggests the following basic conclusions with respect to the connection between international human rights law and democratic legitimacy. Human rights law holds the promise of democratising effects, as the Moroccan case may illustrate. However, neither democracies nor non-democracies contain a national process of the incorporation of human rights which may be accurately described as democratic - at least if the definition of such a democratic process is one which provides citizens with an opportunity for voice through direct participation or representation.

Indeed, the incorporation of human rights law is similar in its elite-driven nature whether one looks at the United States or Arab countries. In both contexts, political insiders and elite outsiders engage in a process of careful contestation that is geared towards pressuring government executives to endorse or extend international rights. This process may differ in significant respects across

56 See ibid and Marguerite Rollinde Le mouvement marocain des droits de l'Homme: Entre consensus national et engagement citoyen (Collection hommes et sociétés, Paris, 2002).

57 Ottoway and Riley, above $n 53$.

58 Mednicoff, above n 40. 
regimes, or even regime types, with respect to the involvement of judges, the salience of international NGOs, or the level of rights repressions at stake. Yet, democracies cannot claim special privilege in engaging most citizens in a participatory or representative way with international human rights. The Moroccan case hints at a process that is driven sufficiently by the sustained efforts of a wide range of indigenous political actors to enhance rights to be considered quasidemocratic.

How critical is this democratic deficit for the domestication of international rights law? I have noted above some responses to this question, including the argument that the ultimately egalitarian effects of the proliferation of human rights may matter more than the problems of democratic accountability of the process. One can also argue that elitist law-making is politically desirable, efficacious or inevitable. On the first two points, many American jurists and activists would no doubt fear, with some basis, excessive democratic accountability for issues of rights regarding race, gender, or sexual orientation. Indeed, it is easy to see international law's domestic and transnational processes as similar to national legal processes, which combine a variety of actors, without reflecting badly on democratic legitimacy. ${ }^{59}$

Despite these arguments, I maintain that the democratic deficit in international law is problematic for several reasons. First is the simple concern that, in fact, ordinary Americans and Arabs have little actual choice in how international laws are applied to them, even though they are in fact subject to these laws in myriad ways. This, in turn, provides little incentive for many people to support international law when their governments claim that it conflicts with national legal norms or practice.

In the Arab cases, one can raise questions about what interests are advanced and whether quasicolonial politics emerges from viewing political activism mostly through the lens of human rights. ${ }^{60}$ As for the United States, the extension of international laws into the domestic legal system, through a process that avoids widespread accountability to citizens, fails to ground these laws in popular domestic understanding and support, threatening their ultimate staying power. If international human rights seem so distant and poorly understood to many Americans, it may not be surprising that little mass protest erupts when specific aspects of these rights are eroded by leaders, as has been the case since $9 / 11 .{ }^{61}$ A process that engages and links diverse political elites and frames

59 Koh, above n 19, 55

60 Rajagopal, above n 39, 230-2.

61 See, for example, the reports noted in Human Rights First (formerly the Lawyers' Committee for Human Rights) 2005 Publications Catalogue (Human Rights First, New York, 2005), including A Year of Loss: Reexamining Civil Liberties Since September 11 (Human Rights First, New York, 2002); Imbalance of Power: How Changes to US Law \& Security Policy Since 9/11 Erode Human Rights and Civil Liberties (Human Rights First, New York, 2003); Assessing the New Normal: Liberty and Security for PostSeptember 11 United States (Human Rights First, New York, 2003); Jeremy Waldron "Torture and Positive Law: Jurisprudence for the White House" (2005) 105 Colum L Rev 1681; Phillipe Sands Lawless World: 
international rights issues to a broader public, as has taken place in Morocco in the past few decades, offers a model for the quasi-democratic domestication of international law that stands a chance of rooting global rights in firm ground.

Indeed, supporters of the international human rights movement have begun to emphasise recently the need for advocates to link their activism to a wider public, thereby building more popular consensus, and by implication, quasi-democratic legitimacy, for human rights. ${ }^{62}$ Human rights NGOs face a constant dilemma navigating between their dedication to political neutrality and a stance that will connect them to broader sociopolitical struggles. While it can be claimed that realising human rights globally is the obligation of all people, ${ }^{63}$ such claims presume widespread understanding of the nature of human rights.

In the United States, law is generally a subject limited to post-graduate students wishing to become elite legal professionals. In Arab countries, the study of law enjoys little prestige, which may be commensurate with the relatively low autonomy and the relatively high association with colonial and post-colonial bureaucracies that have characterised the legal profession in the Middle East and North Africa. Broader understanding of international law may be necessary to encourage its widespread acceptance and advocacy. Concerns about possible incompatibilities between international law and domestic legal influences, such as traditional Islam, cannot be addressed simply by avoidance, which is easy to do when discourse and contestation on rights remain confined to a narrow elite. ${ }^{64}$

This indicates a second, related problem. Popular support for human rights matters because leaders often feel an incentive to restrict or repress them. Raising democratic legitimacy concerns in the domestication of international human rights law heightens the risk that such law will be portrayed by government officials as unresponsive to national norms when this suits their goals. As arguments that international law lacks effectiveness begin to lose steam in light of the very real growth in its content and in theories about why states obey, ${ }^{65}$ leaders seeking to justify violations can easily claim that international law is unrepresentative of their citizens' will. In recent years in the United States, this claim has served as a rationalisation for policies, such as the 2003 American

The Whistle-blowing Account of how Bush and Blair are Taking the Law into their Own Hands (Penguin, New York, 2006).

62 See, for example, David Kennedy The Dark Sides of Virtue: Reassessing International Humanitarianism (Princeton University Press, Princeton, 2005) 8-35 and David Rieff $A$ Bed for the Night: Humanitarianism in Crisis (Simon \& Schuster, New York, 2002) 8-9.

63 See, for example, Ken Booth "Three Tyrannies" in Tim Dunne and Nicholas J Wheeler (eds) Human Rights in Global Politics (Cambridge University Press, New York, 1999) 31, 62-3.

64 Modirzadeh, above n 45, 197-203.

65 See, for example, Franck, above n 4, 4-8. 
invasion and occupation of Iraq, that are also grounded in the claim that fealty to international law is merely one of a number of competing possible national interests. ${ }^{66}$ Without a mechanism for the national incorporation of international law with some accountability to citizens, democratic systems like the United States differ little from their non-democratic counterparts in their leaders' ability to use populist arguments based upon the perceived elitism of international legal standards.

This concern is particularly worrisome with respect to international human rights law, and merits more focused consideration. The more that the national enforcement of basic international civil and political human rights lends itself to easy claims of domestic popular illegitimacy, the more officials have leeway to curtail these rights and act behind a curtain of unaccountability. This is not a theoretical problem; it is illustrated by the Bush Administration's response to the events of 9/11/01. ${ }^{67}$ It has also been a common response of Arab governments to local and international charges of human rights abuses.

Indeed, the democratic legitimacy problem may not merely facilitate American and Arab leaders' justifications of human rights abuses, it may foster a loose system in which such justifications play off and reinforce each other. Democratic and non-democratic governments use their relations with one another in at least two ways to strengthen their own authority and minimise the potential threat that international human rights law can pose to this authority.

On the one hand, politicians and officials in both systems can deny the need to enforce international human rights law by exaggerating their own contrast with the perceived other regime type. Non-western governments often claim that they shouldn't domesticate international human rights because this body of law is a western colonial construct forced on them in a neo-imperial manner. Similarly, some western governments, such as the United States, have argued that the refusal of authoritarian systems to observe basic human rights can justify American lapses in rights enforcement or enhanced executive authority. ${ }^{68}$ In other words, leaders in the United States and Arab countries may deliberately inflate and depend on the democracy-authoritarian distinction to make populist appeals to their domestic constituencies against the local strengthening of international law.

66 Thomas M Franck "The Power of Legitimacy and the Legitimacy of Power: International Law in an Age of Power Disequilibrium." (2006) 100 Am J Int'l L 88, 89.

67 See, for example, Elizabeth Drew "Power Grab" (2006) 53(11) New York Review of Books.

68 See, generally, Donnelly, above n 2 and Reed Brody "Right Side Up" in Human Rights Watch World Report 2004 (Human Rights Watch, New York, 2004) 376, 380, 385-8. Much of the justification of governments to carve exceptions for human rights in reference to other types of regimes and arguments about power has been framed in terms of often artificial or static ideas about national culture. See, generally, Mahmoud Mamdani (ed) Beyond Rights Talk and Culture Talk: Comparative Essays on the Politics of Rights and Culture (Palgrave, New York, 2000). On the need for enhanced United States executive power in the aftermath of 9/11, including a discussion of "rogue states," see John Yoo "War, responsibility, and the age of terrorism" (2004) 57 Stan L Rev 793. Yoo served in the Bush Administration from 2001 through 2003. 
On the other hand, democratic and non-democratic regimes can find common ground in repressing the human rights of people under their jurisdiction on the theory that these people themselves do not respect international law. Thus, the United States and the governments of Egypt and Tunisia have reinforced each other's restrictions on the rights of Islamist activists since 9/11 by claiming that such activists care little for human rights in either their theocratic goals or their violent methods. ${ }^{69}$ Such cases of cooperative political repression against alleged terrorists or radicals may not depend directly on the democratic legitimacy problem of human rights. Nonetheless, by feeding into activist movements' own potential to dismiss the legitimacy of international legal norms, the democratic deficit of human rights allows Washington and Arab governments to support each others' arguments that they should not be required to apply human rights standards to opponents who themselves refuse to abide by these standards.

To be sure, governments can be expected to rebuff charges of human rights violations with some version of a claim that they are acting in their citizens' best interest. Yet, the complex ways in which transnational elites working on international human rights law can simplify or misrepresent the vibrancy of the local contestation of relevant issues ${ }^{70}$ may magnify the gap between the aspirations and perceived local legitimacy of this body of law. Thus, the democratic deficit of international human rights law, and the particular interconnection between how this deficit often plays out in democracies and non-democracies, enhances the risk of human rights repression.

If international lawyers value growing global legality and institutionalisation, the political consequences of the democratic deficit problem cannot be easily ignored. I have focused on the comparative incorporation of human rights law in the United States and the Middle East, but the problem plays out in other forms and places. Another cogent example is the 2005 defeat of the proposed European Constitution through national ratification processes. In line with my argument above, the laws and institutions of the European Union may not suffer from a deep democratic deficit, but may simply need enhanced support through reducing cognitive and normative dissonance between elites and the public. ${ }^{71}$ One analyst has gone so far to suggest that increased domestic popular involvement in the European Union may be unnecessary, so long as careful

69 See, for example, President Bush's description of Guantanamo Bay detainees in his speech of 9/06/06, available at www.whitehouse.gov (accessed 1 May 2007); President Hosni Mubarak of Egypt used a similar logic in a speech to Egyptian police on 1/25/03, which can be found at: http://www2.sis.gov.eg. Human Rights Watch World Report 2007 (Human Rights Watch, New York, 2007) is laced with examples of restrictions on freedom of expression and other human rights in the post-9/11 US and Arab contexts: see $63,66,71-2,75-6,462,519$ and 522-3

70 Merry, above n 34, 16-19.

71 Paul Magnette "Does the Process Really Matter? Some reflections on the "legitimating effect" of the European Convention" 102 Harvard Center for European Studies Working Paper Series 20-1. 
analysis occurs of the "varied dynamics of counter-majoritarian situations ... [through] analysing the specifics of the intervening political processes." ${ }^{172}$

However, the arguments in France and the Netherlands, the countries in which national referenda were held on the European Constitution proposal, included charges of European transnational elitism and more subtle critiques about the way western-based international legal globalisation can be embedded in a market economic determinist stance. ${ }^{73}$ Though the French coalition against the Constitution was diverse, one influential theme was the populist appeal against the "Polish plumber," the personification of nationalist fears of the loss of control over local labor markets and identity based on trumped-up fears of someone from a different political system. The French "non" played into and was reinforced by mobilisation efforts against the Constitution in other European states. Thus, the politics of the European Constitution referenda suggest both the general relevance of the democratic deficit problem in transnational legalisation and the tendency for this problem to play out cross-nationally in an area other than human rights.

If international law's democratic deficit in diverse contexts matters enough to enable and encourage popular acceptance of government violations in such critical areas as basic human rights, what can mitigate the problem? Obviously, no more direct solution exists than heightened democratic participatory and/or representative voice in the domestic incorporation of international law. Of course, one can debate the desirability of this in terms of its potential to yield outcomes unfavorable to international law, such as the aforementioned results of the European constitutional referenda, gay rights in the United States, or human rights considered to challenge Islamic law in some Arab contexts.

In any case, the global diversity of political systems and governments' frequent interests in limiting the domestic scope of international law make a generalised democratic solution to the legitimacy problem unlikely. For this reason, a quasi-democratic process for the internalisation of international law might be more feasible. An example of this is Morocco's recent, increasingly broad contestation and expansion of human rights. Such a process acknowledges political and legal differences among regimes, but insists that some breadth and depth in the domestic contestation of international law offers the chance to internalise transnational norms on a firm, popular foundation.

Socio-legal scholars have much less influence over implementing populist political strategies than over what they research. Given this, perhaps the most significant strategic implication of my discussion of the domestic politics of recent international rights in the United States, Morocco and

72 Andrew Moravcsik "What Can we Learn from the Collapse of the European Constitutional Process?" 47 Politische Vierteljahresschrift (2006) 219, 239.

73 See, for example, Bernard Cassen "Après le 29 mai: Ruptures européennes» (April 2006) Le Monde Diplomatique 29 and Serge Halimi, «Les promesses du «non»: Quand la gauche renonçait au nom de l'Europe» (June 2005) Le Monde Diplomatique 20. 
Tunisia is the central need for the comparative study of international law. By comparative international law, I mean to describe two kinds of work. First, we need to study specific similarities and differences in how international law is understood, contested, and implemented in diverse societies. Thus, building on my work here, it may be that more detailed analysis than is possible in this short essay would reveal specific common patterns and divergences in the interplay of elite and popular domestic politics of international human rights law in the United States, Morocco and Tunisia.

Second, comparative international law as I understand it should consider what connections, if any, exist across societies with respect to the politics and law of global legal norms. Hence, it would be useful to refine, operationalise and test hypotheses like the one I advance here that regimes like the United States and Tunisia both play off exaggerated senses of differences with each other and express common commitments to combating perceived threats like violent Islamism to justify similar domestic rights violations.

In particular, comparative international law should include attention to non-western and nondemocratic contexts. With respect to the democratic legitimacy problem of human rights, I have suggested that US government ambivalence towards rights domestication after 9/11/01 can be understood in its relation to and reflection of analogous processes in Arab states. ${ }^{74}$ Thus, a focus on international law's democratic legitimacy problem that is limited to Western democracies risks losing critical or systemic political dimensions of this problem.

Incorporating non-western cases in comparative international legal studies is useful for at least two other reasons. First, these cases represent most of the world's population. Less obviously, but implied by my analysis of human rights incorporation in Morocco and Tunisia, potential resolutions to the democratic dilemmas of international law may well be most salient or innovative where countries are in a period of rapid contestation and change. Such a period may involve the application international legal norms, as opposed to where these norms are endemic enough to risk retrenchment, as may be said to be the position in the United States since 9/11. Efforts to analyse how and why democracies may resemble non-democracies in international law's domestic vulnerability to elitist and anti-majoritarian charges at least allow for democratic deficit concerns to be debated and addressed substantively and empirically in their diverse forms.

Scholars of world politics have been aware for some time of escalating tensions between transnational and parochial forces. ${ }^{75}$ Such tensions manifest themselves in diverse ways with

74 See, for example, Jason Brownlee "Political Crisis and Restabilization: Iraq, Libya, Syria and Tunisia," in Marsha Pripstein Posusney and Michele Penner Angrist (eds) Authoritarianism in the Middle East: Regimes and Resistance (Lynne Rienner Publishers, Boulder (Colorado), 2005) 43, 59-60.

75 See, for example, Benjamin Barber Jihad vs McWorld: How Globalism and Tribalism are Reshaping the World (Ballantine Books, New York, 1996). 
respect to the local adaptation of international human rights. ${ }^{76}$ The combination of growing globalisation and American post-9/11 global assertion spells new challenges for international law. This is especially true since some leaders who are cynical about human rights can be less hesitant than scholars to use international law's democratic legitimacy problems to fan the flames of nationalist or religious particularism. Recognising the rhetorical populist appeal of democratic problems with international law, the way such problems have been addressed in states such as Morocco, and the interconnections among diverse regimes with respect to these problems, may address this appeal better than minimising the problems.

76 Merry, above n 34. 
